\title{
Diagnostic System to Determine Lining Condition
}

\author{
Vitaliy Yemelyanov ${ }^{1, *}$, Nataliya Yemelyanova $^{1}$, and Alexey Nedelkin $^{2}$ \\ ${ }^{1}$ Financial University under the Government of the Russian Federation, 49 Leningradsky Prospekt, Moscow, 125993, Russia \\ ${ }^{2}$ Plekhanov Russian University of Economics, 36, Stremyanny Lane, Moscow, 117997, Russia
}

\begin{abstract}
The paper presents data on the problem of diagnosing the lining condition at the iron and steel works. The authors propose and describe structure of specialized computer system to diagnose critical lined equipment. The relative results of lining condition diagnosing by the basic system and proposed specialized computer system are presented. To automate evaluation of lining condition and support in making decisions regarding operation mode of the lined equipment, the specialized software has been developed.
\end{abstract}

\section{Introduction}

In the course of industrial production, dangerous and critical production facilities and machinery are used. Lined equipment, including torpedo ladle cars, hot-metal cars and steel ladles are considered to be critical equipment at heavy industry and machinery building facilities. Such equipment is classified as critical since consequences of accidents involving such equipment lead to multimillion losses for the enterprise and in some cases to human deaths, which is proved by a number of sources [1-3]. In order to prevent accidents with such type of equipment and maintain industrial safety at the production facility, a growing number of diagnostic operations and technologies to control technical condition of lined equipment are applied in production units which, in turn, require development of new and improvement of existing technical means and information technologies

Nowadays there are different automated systems to monitor, diagnose and operate critical equipment at production units [4-6]. Existing automated systems possess a wide range of functions to diagnose and monitor the condition of critical equipment; however, as a number of sources claim [5-8], existing systems do not provide diagnostics of the given lined equipment in the real-time mode without stopping exploiting it. It should be mentioned that modern automated systems are unable to provide complete complex (qualitative and quantitative) automated evaluation of the lining condition, which leads to a low level of objectiveness and quality of the decisions taken while exploiting the equipment. Another important factor is that the existing systems are oriented to diagnose only certain equipment and their adaptation to a different production facility requires a lot of time and finance [9-10]. That is why, scientific research in the field of computerization and intellectualization of the lined equipment condition diagnostics is relevant.

\section{The structure of diagnostic system to determine lining condition}

Diagnostic system to determine lining condition presents a combination of technical and software tools as well as a human technician. Figure 1 presents the proposed structure of diagnostic system to determine lining condition.

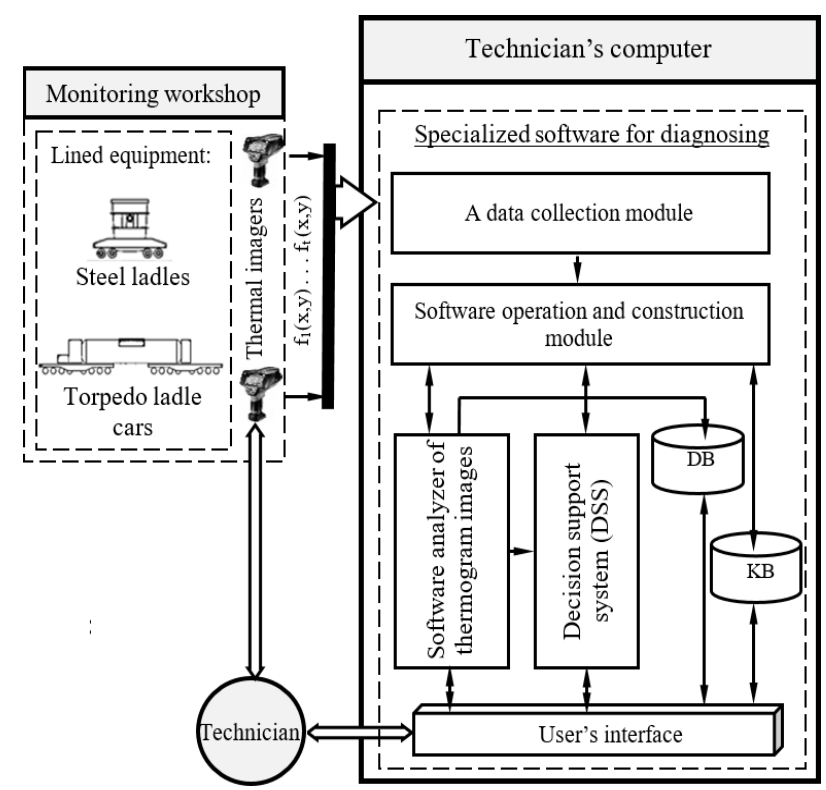

Fig. 1. Proposed structure of diagnostic system to determine lining condition.

According to the structure in figure 1, the system under development includes the following:

1. Thermal imagers to create thermogram images $(\mathrm{ft}(\mathrm{x}, \mathrm{y}))$ of lining. Thermograms are collected by thermal imagers at the monitoring workshop of lined equipment. 
2. The technician's computer with specialized software (figure 2) to automate evaluation of lining condition and support in making decisions regarding operation mode of the lined equipment.

2.1. A data collection module designed to form initial data (thermograms) to diagnose the lining condition.

2.2. Software operation and construction module designed to select and structure methods and models for diagnostics of lined equipment.

2.3. Software analyzer of thermogram images - module designed to apply the proposed by authors intelligent methods and models of thermograms images processing $[9,10]$ in order to diagnose the lining condition.

2.4. Decision support system (DSS) - a program to operate knowledge in the process of technical diagnostics of lined equipment in order to support decision-making concerning selection of operation mode of lined equipment.

2.5. - Knowledge base (KB) - storage of information that includes recommendations and/or knowledge received after technical diagnostics of lined equipment.

2.6 Database - storage of information about diagnostic operations for different types of lined equipment.

2.7. User's interface allowing interaction between a technician and the software.

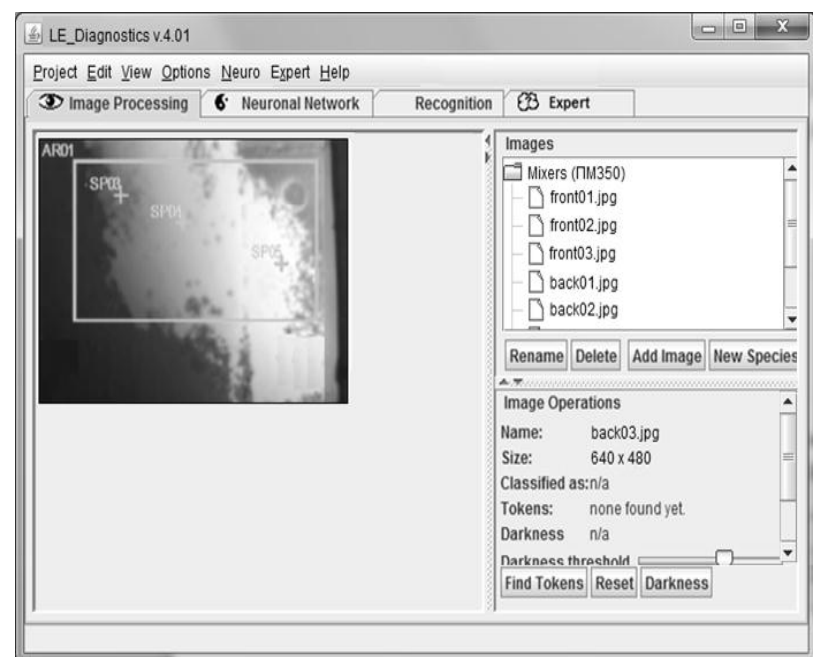

Fig. 2. Developed software to diagnose lining condition (thermograms analyser).

The technician's functions include collection and uploading of primary data into the diagnostic system to allow software to determine technical condition of the lining by processing images of thermograms and to provide required support when making decisions concerning the lined equipment operation mode by implementing of the suggested method $[11,12]$.

\section{Experimental research of developed diagnostic system to determine lining condition}

In order to control effectiveness of proposed solutions, a diagnostic system to determine lining condition was developed. Experimental researching of the developed system were carried out in the shop of weighing facilities of "Alchevsk Iron\&Steel Works". The diagnostic system implemented at "Alchevsk Iron\&Steel Works" was developed as the following software-hardware combination: the technician's computer with developed software (processor - Intel Core i5 2,4 GHz; operating memory - 8 GB DDR4), thermal imagers FLIR GF309.

The proposed solutions were used to determine and evaluate burnout zones of lining. Thermal imagers were used to form thermograms' images for the following 4 types of critical lined equipment used at "Alchevsk Iron\&Steel Works": immovable mixer MC-1300, torpedo ladle car PM350, hot-metal car 100 tonnes, steel ladle 50 tonnes. On completion of this stage, the developed software was used to recognise the thermograms' images, which is demonstrate in figure 3.
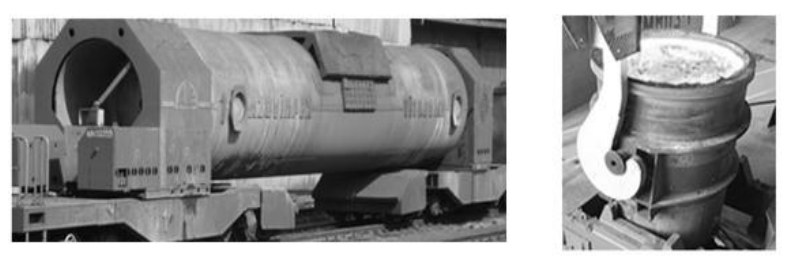

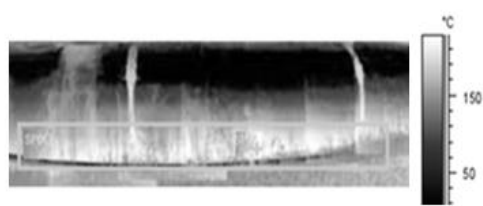

a)

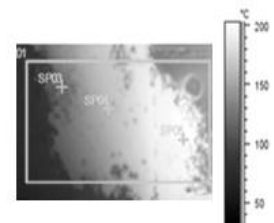

b)
Fig. 3. Thermograms of lined equipment (lining burnout zones): a - torpedo ladle car PM350 and its thermal image; b steel ladle 50 tonns and its thermal image

During the experimental evaluation of effectiveness of the developed diagnostic system, the index of statistical reliability of lining condition diagnostics was calculated as a degree of correspondence between the number of identified lining burnout zones according to the thermal image and the number of really existing lining burnout zones, proved in the course of the experiment. Statistical reliability of lining burnout zones determined by thermal images is calculated as:

$$
D=N / N r
$$

where $N$ - the number of identified burnout zones according to the thermal images;

$\mathrm{Nr}$ - the number of burnout zones which were proved in the course of experiment.

Also the operativeness of the technical diagnostics was calculated. It is proposed to use the approach which evaluates the operativeness of diagnostics of the lining condition for a given software-hardware combination of the specialized system describes above.

Table 1 illustrates the results of identifying images of critical lines equipment thermograms with determination of basic indicators of diagnostic efficiency. 
Table 1. Relative results to diagnose lining condition by the basic system and developed system.

\begin{tabular}{|c|c|c|c|c|}
\hline \multirow{2}{*}{$\begin{array}{c}\text { Lined } \\
\text { equipment }\end{array}$} & \multicolumn{2}{|c|}{$\begin{array}{c}\text { Basic } \\
\text { diagnostic system } \\
\text { (pyrometers to } \\
\text { determine burnout } \\
\text { zones) }\end{array}$} & \multicolumn{2}{|c|}{$\begin{array}{c}\text { Developed } \\
\text { diagnostic system }\end{array}$} \\
\hline & $\begin{array}{l}\text { Statistical } \\
\text { reliability }\end{array}$ & $\begin{array}{c}\text { Operativ } \\
\text { eness, } \\
\text { average } \\
\text { (min) }\end{array}$ & $\begin{array}{l}\text { Statistical } \\
\text { reliability }\end{array}$ & $\begin{array}{c}\text { Operativ } \\
\text { eness, } \\
\text { average } \\
\text { (min) }\end{array}$ \\
\hline $\begin{array}{l}\text { Immovable mixer } \\
\text { MC-1300 }\end{array}$ & 0.90 & 62 & 0.93 & 25 \\
\hline \multirow{4}{*}{$\begin{array}{l}\text { Torpedo } \\
\text { ladle cars } \\
\text { (type PM350) }\end{array}$} & 0.86 & 70 & 0.96 & 25 \\
\hline & 0.88 & 65 & 0.92 & 30 \\
\hline & 0.88 & 73 & 0.96 & 28 \\
\hline & 0.87 & 80 & 0.94 & 33 \\
\hline $\begin{array}{l}\text { Hot-metal car } \\
100 \text { tonnes }\end{array}$ & 0.85 & 30 & 0.97 & 15 \\
\hline $\begin{array}{l}\text { Steel ladle } \\
50 \text { tonnes }\end{array}$ & 0.89 & 27 & 0.96 & 13 \\
\hline
\end{tabular}

Analysis of the data from Table 1 provides information about increased effectiveness of critical lined equipment diagnostics in comparison with the standard diagnostic system, which is expressed in increased reliability and efficiency of burnout zones determination in the course of diagnostics.

\section{Conclusions}

The following results were received in the course of the study:

1. The structure of diagnostic system to determine lining condition has been proposed and described.

2. Diagnostic system to determine lining condition, which allowed to increase critical lined equipment diagnostics effectiveness due to automation of data processing and implementation of artificial intelligence methods, was developed and implemented in the shop of weighing facilities of Alchevsk Iron\&Steel Works.

3. Effectiveness of critical lined equipment technical diagnostics was improved which resulted in higher efficiency and reliability in determination of lining burnout zones.

\section{References}

1. T. Fredman, J. Torrkulla, H. Saxe'n, Metallurgical And Materials Transactions B, 30B, 323-330, (1999)
2. N. Schmitt, F. Hild, E. Blond, Advances in refractories for the metallurgical industries, IV, 3951, (2004)

3. L. Doukovska, V. Petkov, E. Mihailov, S. Vassileva, Cybernetics and information technologies, 12(4), 66-76, (2012)

4. V. Petkov, M. Hadjiski, K. Boshnakov, E. Mihailov, Cybernetics and information technologies, 13(2), 66-76, (2013)

5. C. Almeida, W. Camihas, A. Braga, V. Padiva, H. Martins, R. Torres, Proc. of SPIE, 5782, (2005)

6. Y. Sun, D. Zhang, M. Yang, Y. Tang, Proc. Int. Conf. on Mechanic Automation and Control Engineering, 2589-2592, (2012)

7. A.V. Zabolotsky, Journal of Engineering Physics and Thermophysics, 84(2), 342-347, (2011)

8. Y. Gordon, S. Kumar, M. Freislich, Y. Yaroshenko, Steel in Translation, 45(9), 627-634, (2015)

9. M. Fidali, Proc. of the 9th Int. Conf. on Quantitative Infrared Thermography, 123-130, (2008)

10. S. I. Luk'yanov, E. S. Suspitsyn, S. S. Krasil'nikov, M. V. Konovalov, Metallurgist, 58, 310-315, (2014)

11. V.A. Yemelyanov, Naukovyi Visnyk Natsionalnoho Hirnychoho Universytetu, 6, 137-143, (2014)

12. V.A. Yemelyanov, Naukovyi Visnyk Natsionalnoho Hirnychoho Universytetu, 4, 66-73, (2014) 